\title{
THE ISOLATION OF SYMBIOTIC STREPTOCOCCI
}

\author{
R. H. GEORGE \\ Department of Virology, University of Birmingham, and Department of Pathology, \\ Birmingham Maternity Hospital
}

SAtellitism is a phenomenon usually associated with Haemophilus, but there have been reports of occasional strains of other organisms, including streptococci, that exhibit this property. My interest in this subject was aroused by the isolation in 1972 of a streptococcus showing satellitism to Escherichia coli. This strain was cultivated at necropsy from the trachea of a stillborn baby. Since then, three further isolations have been made from human material and three additional strains obtained through the kindness of Dr K. B. Rogers.

This paper reports the properties and growth requirements of these seven strains of symbiotic streptococci. Pyridoxine hydrochloride was found to support the growth of these organisms, and its inclusion in routine diagnostic media was therefore examined for possible adverse effects on the isolation of potential pathogens.

\section{MATERIALS AND METHODS}

\section{Streptococci}

Strain 1 was isolated in Feb. 1972 at the Birmingham Maternity Hospital, strain 2 in Mar. 1972 at the Queen Elizabeth Hospital, Birmingham (QEH) as a satellite to a micrococcus in a culture of a vaginal discharge, and strain 3 at QEH in May 1972 from a case of otitis externa. Strain 4 was isolated in June 1972 from a dilution of the author's saliva on pyridoxine-containing blood agar, and subsequent replica plating on to the same medium without pyridoxine. Strains 5, 6 and 7 were provided by Dr K. B. Rogers and had been isolated in Oct. 1972 at the Birmingham Children's Hospital from mixed wound infections.

\section{Examination of the streptococci}

Oxoid Blood Agar no. 2 containing 5\% horse blood was used as the basal medium in which growth factors were incorporated. Satellitism to other organisms was also tested on this medium. All plates were inoculated over the entire surface with the streptococcus to be tested, and organisms being examined for their ability to support growth of the streptococcus were streaked across the plate. One strain of staphylococcus was streaked across as a control when testing growth factors, so that inhibition of growth of satellitic streptococci by any of these substances might be detected.

Growth of the streptococci was also examined in Bacto Thiol Broth (Difco), in Robertson's Cooked Meat (Oxoid), and on Oxoid Blood Agar Base no. 2 with either 5\% horse serum, $20 \%$ sucrose or $5 \%$ sodium chloride.

Antibiotic-sensitivity tests were performed by a disk-diffusion method with " Mast" disks, on Diagnostic Sensitivity Test Agar (Oxoid) containing 5\% saponin-lysed horse blood, with or without pyridoxine hydrochloride $1 \mu \mathrm{g}$ per $\mathrm{ml}$. Control organisms used in these tests were the Oxford staphylococcus (NCTC no. 6571), E. coli (NCTC no. 10418) and a strain of Streptococcus faecalis. Salt agar was used for methicillin- and cloxacillin-sensitivity tests. All antibiotics were tested in triplicate, and the zones measured with vernier calipers. 
Other properties of the strains were determined on $5 \%$ horse-blood agar, on MacConkey Agar (Oxoid) and in Todd-Hewitt Broth (Oxoid), all enriched with pyridoxine hydrochloride $1 \mu \mathrm{g}$ per $\mathrm{ml}$. Lancefield grouping was performed with antisera (Burroughs Wellcome) for groups A-R on extracts made by the method of Fuller (1938).

Requirement for growth factors. $\mathrm{X}$ and $\mathrm{V}$ factors were applied as disks (Mast Laboratories). The other substances tested were supplied as powder by British Drug Houses unless otherwise stated. Each was dissolved in distilled water, with the exception of a few substances that were first dissolved in dilute sodium hydroxide or dilute hydrochloric acid and then diluted in distilled water. The following amino-acids, purines and pyrimidines were tested individually and as a mixture to give final concentrations of each, whether alone or in combination, of $10 \mu \mathrm{g}$ per $\mathrm{ml}$ in the agar: adenine, DL-alanine, L-arginine, L-asparagine, L-aspartic acid, L-cystine (Difco), L-cysteine, cytosine, L-glutamic acid, L-glutamine, glycine, L-histidine, L-hydroxyproline, L-isoleucine, L-leucine, L-lysine, L-methionine, L-ornithine, L-phenylalanine, L-proline, L-serine, taurine, L-threonine, thymine, L-tryptophan, L-tyrosine, uracil, L-valine. The fatty acids-stearic acid and oleic acid-were tested individually at final concentrations of $100 \mu \mathrm{M}$ and at $1 \mu \mathrm{M}$. The vitamins, L-ascorbic acid, $p$-amino-benzoic acid, D-biotin, choline chloride, folic acid, nicotinic acid, calcium pantothenate, pyridoxine hydrochloride, riboflavin and thiamine hydrochloride were tested alone, as a mixture and as a mixture with the amino acids, purines and pyrimidines, at final concentrations of each of $1 \mu \mathrm{g}$ per $\mathrm{ml}$ and $0.05 \mu \mathrm{g}$ per $\mathrm{ml}$ in the agar.

Strain 2 was also tested against D-alanine (Sigma) and L-alanine.

\section{Tests on other organisms}

The following organisms were tested for their ability to support satellite growth of the streptococci (the number of strains of each organism is given in parenthesis): micrococci (3), staphylococci (3), streptococci of group A (2), group B (1), group D (1), group G (1), Corynebacterium diphtheriae (1), Neisseria pharyngis (1), E. coli (3), Klebsiella aerogenes (3), Pseudomonas aeruginosa (3), Proteus mirabilis (1, a non-motile variant), Salmonella typhimurium (1), Candida albicans (2), Bacillus subtilis (1), and a brewers' yeast (1).

The same organisms, except for the strain of Bacillus subtilis and the brewers' yeast, were also used in experiments in which $1 \mu \mathrm{g}$ per $\mathrm{ml}$ of pyridoxine hydrochloride was incorporated into a variety of routine laboratory media. Colony counts of these organisms, from suspensions in Nutrient Broth (Oxoid), were compared on media with and without growth factor after incubation at $37^{\circ} \mathrm{C}$ for 24 hours and 48 hours by the method of Miles, Misra and Irwin (1938).

\section{RESULTS}

\section{Morphology and growth requirements of the streptococci}

At the time of isolation of strain 1, it was observed that whereas colonies of the organism taken from the immediate vicinity of the " host " colony consisted of Gram-positive cocci in chains, organisms taken from the outer edge of the zone of satellitism were Gram-negative and pleomorphic, with filamentous and globular forms. A similar picture was given by the other six strains, and was repeatedly confirmed when the organisms were restored to satellite growth after serial subculture on media containing the growth factor.

This observation suggested that the factor deficient in normal medium might be concerned in cell-wall formation, but none of the seven isolates grew or produced L-form like colonies on media containing salt, sucrose or serum.

Incubation under anaerobic conditions or in the presence of $10 \%$ carbon dioxide did not permit growth on the basal medium. The provision of $\mathrm{X}$ or $\mathrm{V}$ 
factors was likewise without effect. However, each of the strains grew in Cooked-Meat Medium and Bacto Thiol Broth.

Tests with other bacteria and fungi revealed that the ability to support satellite growth was a very common property. All the organisms tested supported the growth of the seven strains, but noticeably narrower bands of growth with smaller colonies were obtained with Cand. albicans, B. subtilis and Coryne. diphtheriae than with the rest.

In the experiments in which amino acids, purines, pyrimidines, vitamins and fatty acids were added to the basal medium, either individually or in mixtures, pyridoxine hydrochloride was found to support the growth of all seven strains. Growth of strain 2 also occurred in the presence of DL-alanine, and subsequent

TABLE I

Properties of the symbiotic streptococcal strains

\begin{tabular}{|c|c|c|c|c|c|}
\hline Strain & Haemolysis & $\begin{array}{l}\text { Lancefield } \\
\text { group } \\
\text { antigen } \\
\text { detected }\end{array}$ & $\begin{array}{c}\text { Stimulation } \\
\text { by } \\
\text { D-alanine }\end{array}$ & $\begin{array}{c}\text { Pyridoxine } \\
\text { concentration } \\
\text { allowing } \\
\text { growth }(\mu \mathrm{g} \text { per } \mathrm{ml})\end{array}$ & $\begin{array}{c}\text { Pyridoxine } \\
\text { concentration for } \\
\text { maximal colonial } \\
\text { size }(\mu \mathrm{g} \text { per ml })\end{array}$ \\
\hline $\begin{array}{l}1 \\
2 \\
3 \\
4 \\
5 \\
6 \\
7\end{array}$ & $\begin{array}{c}\text { None } \\
\alpha \\
\text { None } \\
\text { None } \\
\alpha \\
\alpha \\
\beta\end{array}$ & $\begin{array}{c}\text { None } \\
\text { None } \\
\text { None } \\
\text { None } \\
\text { None } \\
\text { None } \\
\text { F }\end{array}$ & $\begin{array}{l}\text { No } \\
\text { Yes } \\
\text { No } \\
\text { No } \\
\text { No } \\
\text { No } \\
\text { No }\end{array}$ & $\begin{array}{l}0 \cdot 025 \\
0 \cdot 1 \\
0 \cdot 1 \\
0 \cdot 1 \\
0 \cdot 1 \\
0 \cdot 1 \\
0 \cdot 1\end{array}$ & $\begin{array}{l}0.1 \\
0.2 \\
0.2 \\
0.2 \\
0.2 \\
0.2 \\
0.2\end{array}$ \\
\hline
\end{tabular}

tests showed this to be due to D-alanine, the L-isomer being inactive. All other compounds tested were without activity either in supporting growth or in antagonising satellite colonies around a staphylococcus.

The minimum concentration of pyridoxine hydrochloride necessary for growth was $0.1 \mu \mathrm{g}$ per $\mathrm{ml}$, except in the case of strain 1, which grew in the presence of $0.025 \mu \mathrm{g}$ per $\mathrm{ml}$ (table I). Colonial size was maximally enhanced by concentrations 2- to 4-fold higher than these limiting concentrations.

\section{Other properties of the streptococcal strains}

Further tests on the streptococci were made on media supplemented with pyridoxine hydrochloride. Under these conditions, the morphology of all strains was consistently that of a Gram-positive coccus in chains. Growth on supplemented blood agar occurred both aerobically and anaerobically and was unaffected by increased amounts of carbon dioxide. Haemolysis was variable; strain 7 gave $\beta$-haemolysis and was the only strain that could be grouped by Lancefield's method (group F). Three of the others gave $\alpha$-haemolysis, while the rest were non-haemolytic (see table I). None of the strains grew on supplemented MacConkey agar. All were sensitive to penicillin, ampicillin, cephaloridine, erythromycin, chloramphenicol, and co-trimoxazole. Strains 
3,4 and 7 differed from the rest in being resistant to tetracycline and sulphonamide.

\section{Effect of pyridoxine on human pathogens}

The above experiments suggested that pyridoxine hydrochloride $1 \mu \mathrm{g}$ per ml could with advantage be added to routine diagnostic media. Experiments were made to check that this addition had no unexpected effects on other organisms. A collection of organisms representative of those isolated from clinical material (see Materials and Methods) was examined on pyridoxine-containing media. No alteration in colonial morphology was observed, and in no case was there a difference in the colony counts on media with and without pyridoxine hydrochloride.

\section{TABLE II}

List of antibiotic-sensitivity tests uninfluenced by the presence of $1 \mu \mathrm{g}$ per $\mathrm{ml}$ of pyridoxine hydrochloride in the medium

\begin{tabular}{|c|c|c|c|c|c|}
\hline Antibiotic & $\begin{array}{c}\text { Disk } \\
\text { content } \\
(\mu \mathrm{g})\end{array}$ & $\begin{array}{c}\text { Organisms } \\
\text { tested }\end{array}$ & Antibiotic & $\begin{array}{c}\text { Disk } \\
\text { content } \\
(\mu \mathrm{g})\end{array}$ & $\underset{\text { tested }}{\text { Organisms }}$ \\
\hline $\begin{array}{l}\text { Ampicillin } \\
\text { Carbenicillin } \\
\text { Cephaloridine } \\
\text { Chloramphenicol } \\
\text { Clindamycin } \\
\text { Cloxacillin } \\
\text { Colistin } \\
\text { Erythromycin } \\
\text { Framycetin } \\
\text { Fusidic acid }\end{array}$ & $\begin{array}{r}25 \\
100 \\
5 \\
25 \\
2 \\
5 \\
50 \\
5 \\
50 \\
10\end{array}$ & $\begin{array}{l}\mathbf{A B C} \\
\mathbf{B} \\
\mathbf{B C} \\
\mathrm{BC} \\
\mathbf{C} \\
\mathbf{C} \\
\mathrm{B} \\
\mathbf{C} \\
\mathbf{C} \\
\mathrm{C}\end{array}$ & $\begin{array}{l}\text { Gentamicin } \\
\text { Kanamycin } \\
\text { Methicillin } \\
\text { Nalidixic acid } \\
\text { Nitrofurantoin } \\
\text { Penicillin } \\
\text { Streptomycin } \\
\text { Sulphonamide } \\
\text { Cotrimoxazole }\end{array}$ & $\begin{array}{r}10 \\
30 \\
10 \\
30 \\
200 \\
1 \\
10 \\
200 \\
25\end{array}$ & $\begin{array}{l}\text { BC } \\
\text { BC } \\
\mathbf{C} \\
\mathbf{B} \\
\mathbf{B} \\
\mathbf{C} \\
\mathbf{B} \\
\mathbf{C} \\
\text { AC }\end{array}$ \\
\hline
\end{tabular}

$\mathrm{A}=$ Streptococcus faecalis; $\mathrm{B}=$ Escherichia coli, NCTC no. 10418; C $=$ Oxford staphylococcus.

The validity of antibiotic tests on medium containing pyridoxine was tested with three organisms and a wide range of antibiotics (table II). No significant alterations in zone sizes were observed.

\section{Discussion}

The organisms other than Haemophilus that show satellitism include $E$. coli (Reitler, Teicher and Valero, 1959), staphylococci, micrococci and diphtheroids (Selwyn and Ellis, 1972) and a filamentous pleomorphic Gram-negative rod capable of independent growth but forming pleomorphic streptococci as satellites around an "air" coccus (Dienes and Pachas, 1971). Frenkel and Hirsch (1961) described non-haemolytic streptococci spontaneously forming L-forms and showing satellitism. These were found to need sulphydryl compounds for cell-wall formation.

The substance secreted by bacteria and yeasts that supports satellite growth, and the substance present in cooked-meat broth, may be pyridoxine or some other analogue of vitamin $B_{6}$. Gale and Epps (1944) demonstrated pyridoxine in all the bacterial species and yeasts tested, and in all animal tissues and fluids 
except urine. Bohonos, Hutchings and Peterson (1942) showed that certain lactic-acid bacteria store pyridoxine in greater concentration than is required for growth, and are capable of its synthesis.

Moller (1938, cited by Bohonos et al., 1942) reported that some lactic-acid bacteria required pyridoxine for growth, and Snell, Guirard and Williams (1942) demonstrated failure of growth of Streptococcus lactis strain $\mathrm{R}$ in the absence of pyridoxine. Woolley and Hutchings (1940) demonstrated the growthsupporting ability of this substance on Streptococcus faecalis var. zymogenes, and more recently Ginsburg and Grossowicz (1957) showed that pyridoxine was an essential substance for the growth of haemolytic streptococci from small inocula.

Pyridoxine has been found to be the most active form of vitamin $B_{6}$ for lactic-acid bacteria (Bohonos et al., 1942), but Olivard and Snell (1955a) found varying activity of vitamin- $\mathrm{B}_{6}$ analogues according to the metabolic pathway studied. Holden, Wildman and Snell (1951) showed the promotion of growth by pyridoxine and hydroxy- and keto-acids, and that these could be dispensed with if appropriate essential amino-acids were provided. Pyridoxal phosphate functions as a coenzyme in transamination (Baddiley and Gale, 1945).

Olivard and Snell (1955a) demonstrated that pyridoxine was required for the formation of D-alanine from L-alanine and subsequent cell-wall formation in Strep. faecalis, and Holden, Furman and Snell (1949) showed vitamin $\mathrm{B}_{6}$ and $\mathrm{D}$-alanine to be mutually replaceable in complex media, suggesting that $\mathrm{D}$ alanine was an essential amino-acid. This may explain the behaviour of my strain 2 , which grew equally well in the presence of $\mathrm{D}$-alanine or pyridoxine.

The morphological appearance of the streptococci, with globular and filamentous Gram-negative forms, suggests that vitamin $B_{6}$ analogues, D-alanine, and the secretion from other bacteria, play some part in cell-wall formation. However, they did not produce L-form-like colonies in osmotically stabilising media, unlike the satellitic streptococci requiring cysteine or other sulphydryl compounds described by Frenkel and Hirsch (1961). It appears that the pyridoxine deficiency in the streptococci described here may have an effect in addition to that on cell-wall formation. It has been reported that pyridoxine permits growth of Strep. faecalis in the absence of cysteine (Olivard and Snell, $1955 b$ ), which suggests that the streptococci of Frenkel and Hirsch might have been capable of growth in pyridoxine-containing media.

The finding of these seven strains of streptococci during a relatively short period suggests that they are not uncommon, and Rogers (1972) has isolated apparently similar organisms consistently from mixed wound infections at the Birmingham Children's Hospital over a period of some years. Several of these belonged to Lancefield group F. Although most of the strains were isolated from pathological lesions, their clinical significance is at present uncertain. The discovery of one strain in the author's mouth suggests that this may be a normal site of carriage of the organisms. Frenkel and Hirsch isolated their sulphydryldependant organisms from patients with otitis externa and bacterial endocarditis. Burdon (1972) isolated streptococci, which could not be subcultured, from the blood of two patients with bacterial endocarditis in Bacto-Thiol Broth 
(Difco), and the strains reported in this paper have also been capable of growth from small inocula in this medium.

The absence of deleterious effects of pyridoxine on antibiotic sensitivity tests, on colonial morphology or on viable counts of human pathogens suggests that this substance can be incorporated routinely into bacteriological media. Further studies of its value in routine use, and of the frequency of pyridoxinedependent streptococci in blood cultures and other clinical material, are planned.

\section{SUMMARY}

Seven strains of streptococci that grow on normal media only as satellite colonies to bacteria and fungi are described. Medium containing pyridoxine hydrochloride in concentration $0.2 \mu \mathrm{g}$ per $\mathrm{ml}$ or greater supported normal growth of all these organisms. One strain grew also on medium containing $10 \mu \mathrm{g}$ per $\mathrm{ml}$ of $\mathrm{D}$-alanine instead of pyridoxine hydrochloride.

Tests for the identification of these strains and determinations of their antibiotic sensitivity were made on media supplemented with pyridoxine hydrochloride.

A concentration of pyridoxine hydrochloride of $1 \mu \mathrm{g}$ per $\mathrm{ml}$ was without effect on the growth and colonial morphology of a series of potentially pathogenic organisms. Antibiotic-sensitivity tests on three selected organisms were likewise unaffected by the compound.

The frequency of occurrence and possible clinical significance of symbiotic streptococci is discussed. It is suggested that pyridoxine hydrochloride can usefully be incorporated in bacteriological media used for routine diagnosis.

The author is indebted to Dr K. B. Rogers for providing cultures of three strains, and to Mrs P. Desai for technical assistance.

\section{REFERENCES}

BADDILEY, J. AND Gale, E. F. 1945. Codecarboxylase function of pyridoxal phosphate. Nature, Lond., 155, 727.

Bohonos, N., Hutchings, B. L. ANd Peterson, W. H. 1942. Pyridoxine nutrition of lactic acid bacteria. J. Bact., 44, 479.

Burdon, D. W. 1972. Personal communication.

Dienes, L. AND PaChas, W. N. 1971. Observations suggesting the development of streptococci from pleomorphic filamentous Gram negative bacteria. Yale J. Biol. Med., 43, 337.

FrenKel, A. AND HiRSCH, W. 1961. Spontaneous development of $\mathbf{L}$ forms of streptococci requiring secretions of other bacteria or sulphydryl compounds for normal growth. Nature, Lond., 191, 728.

FulleR, A. T. 1938. The formamide method for the extraction of polysaccharides from haemolytic streptococci. Br.J. exp. Path., 19, 130.

GALE, E. F. AND EPPS, H. M. R. 1944. Studies on bacterial amino-acid decarboxylases. Biochem. J., 38, 250.

GinsBurG, I. AND Grossowicz, N. 1957. Group A haemolytic streptococci. A chemically defined medium for growth from small inocula. Proc. Soc. exp. Biol. Med., 96, 108.

Holden, J. T., Furman, C. AND SNELl, E. E. 1949. The vitamin $B_{6}$ group. XVI. D alanine and the vitamin $\mathrm{B}_{6}$ content of micro organisms. J. biol. Chem., 178, 789.

Holden, J. T., Wildman, R. B. AND SNell, E. E. 1951. Growth promotion by keto and hydroxy-acid, and its relation to vitamin $\mathrm{B}_{6}$. J. biol. Chem., 191, 559. 
Miles, A. A., MisRa, S. S. AND Irwin, J. O. 1938. The estimation of the bactericidal power of the blood. J. Hyg., Camb., 38, 732.

Olivard, J. AND SNell, E. E. 1955a. Growth and enzymatic activities of vitamin $\mathrm{B}_{6}$ analogues. I. D-alanine synthesis. J. biol. Chem., 213, 203.

Olivard, J. ANd SNell, E. E. 1955 $b$. Growth and enzymatic activities of vitamin $\mathbf{B}_{6}$ analogues. II. Synthesis of miscellaneous aminoacids. J. biol. Chem., 213, 215.

Reitler, R., Teicher, M. AND VAlero, A. 1959. An unusual strain of Escherichia coli in septicaemia as an example of the transformative effect of symbiosis. Nature, Lond., 183, 339.

Rogers, K. B., 1972. Personal communication.

SELWYN, S. AND Ellis, H. 1972. Skin bacteria and skin disinfection reconsidered. Br. med. $J ., 1,131$.

SNell, E. E., Guirard, B. M. AND Williams, R. J. 1942. Occurrence in natural products of a physiologically active metabolite of pyridoxine. J. biol. Chem., 143, 519.

Woolley, D. W. ANd Hutchings, B. L. 1940. Synthetic media for culture of certain haemolytic streptococci. J. Bact., 39, 287. 